\section{International Scientific Journal Theoretical \& Applied Science}

p-ISSN: 2308-4944 (print) e-ISSN: 2409-0085 (online)

Year: $2018 \quad$ Issue: $01 \quad$ Volume: 57

Published: 13.01.2018 http://T-Science.org

SECTION 12. Geology. Anthropology. Archaeology.
Seymur Latif oglu Hasanov

scholar of Ganja Department of Azerbaijan National Academy of Sciences, $\mathrm{PhD}$ of Azerbaijan Technology University Ganja, Azerbaijan seymur.hasanov.85@mail.ru

Elnur Latif oglu Hasanov Corresponding member of International Academy of Theoretical and Applied Sciences, Ph.D., Senior specialist of Ganja Department Azerbaijan National Academy of Sciences, Ganja, Azerbaijan el-hasanov@mail.ru

\title{
APPLIED FEATURES OF COMPARATIVE TECHNICAL, SOCIOLOGICAL INVESTIGATION OF HISTORICAL AND CONTEMPORARY HERITAGE OF AZERBAIJAN
}

\author{
Abstract: In this academic article based on various sources and scientific materials, papers have been \\ researched the main characteristics of historical, also modern natural, socio-economical and cultural heritage of \\ Azerbaijan on the basis of applied approach. \\ For the first time has been investigated the scientific issue on technical and sociological research methods of \\ comparative study of this problem. \\ Key words: Azerbaijan, scientific researches, technical and sociological investigations, sustainable \\ development, model, human development index, historical-cultural heritage, resources. \\ Language: English \\ Citation: Hasanov SL, Hasanov EL (2018) APPLIED FEATURES OF COMPARATIVE TECHNICAL, \\ SOCIOLOGICAL INVESTIGATION OF HISTORICAL AND CONTEMPORARY HERITAGE OF \\ AZERBAIJAN. ISJ Theoretical \& Applied Science, 01 (57): 9-16. \\ Soi: http://s-o-i.org/1.1/TAS-01-57-2 Doi: crossef https://dx.doi.org/10.15863/TAS.2018.01.57.2
}

\section{Introduction}

Azerbaijan has its rich natural and economiccultural traditions. Research of historical development and contemporary issues of investigation of these sources based on comparative academic approach is so important.

Today the large-scaled scientific projects promoting to resolve problems in enterprises and economical branches have been constructed yet in terms of hosted scientific and technological programs of ministries and agencies, Academy of Sciences. In this regard, it is important to establish beneficial cooperative mechanism between small-scale business organizations and enterprises, scientific research establishment.

Modern multicultural societies develop on the deliberate policy of multiculturalism based on the cultural strategies. The demonstration of this is a development of Azerbaijan Republic, where develop representatives of different nations, which integrate into the national culture of Azerbaijan. Rejecting of multiculturalism does not promise anything good, because this path leads through the development of disagreement, phobia, ethnic and religious conflicting of the world $[2,4]$.
Multiculturalism is an important instrument of cultures and civilizations. It is impossible to respect and have a tolerant attitude to the representatives of other cultures without learning their nature, history and achievements. And it is far from the reality to have mutual understanding and establish a dialogue between cultures and civilizations in this case.

\section{Materials and Methods}

Today, the processes in Azerbaijan society are examples of multiculturalism. The Republic of Azerbaijan - a multinational state, so here along with muslims, well as representatives of other religious communities live in peace. Respect and good attitude approach for each individual is characteristic feature of multiculturalism. The policy of multiculturalism are supported by the state.

Azerbaijan from this point of view can not only present their Multicultural Society, but also can be an example for the world in this field. In various countries in the world are trying to study the practice of multiculturalism in Azerbaijan. Azerbaijan is a country where coexist different religions. And the representatives of these religions have always lived in peace, friendship and cooperation. All religious 
monuments in Azerbaijan restore. Atashgah (temple of fire-worshipers) in Baku is the historical past of the Azerbaijani people and it is a monument of Zoroaster (the founder of the religion of fireworshipers) period [25, 118].

Along with the restoration of old religious monuments also built the mosques, synagogues and churches. Above-mentioned demonstrates the development of the Azerbaijani society; it is also an indicator of the state policy here.

So that Azerbaijan is a part of the Islamic world is located at the crossroads of East and West, and is considered as the largest Muslim republic in the Caucasus. The people of Azerbaijan as well as other peoples of the Caucasus have always been loyal to his moral and religious values, and approach to their traditions with respect. In spite of the fact that the majority of the Muslim population of Azerbaijan composes Shiites, Azerbaijan is also home for members of other religions and different ethnic groups. Tolerance and respect to national minorities has been since ancient times, it comes from the time of the Great Silk Road to our times. And this attitude composes the foundation of our country. After acquisition of independence, Azerbaijan has increased the number of men and women from the national minorities who hold high positions in the government of Azerbaijan.

The incidents which happen during the destruction of the Soviet Union become a serious examination for religious and national tolerant traditions of Azerbaijan. In this period Armenians which occupied more than twenty percent $(20 \%)$ of Azerbaijani territory realized a policy of ethnic cleansing which results by more than a million refugees in Azerbaijan. Despite that representatives of civilian population were killed and expelled from their homes, a principle to live in peace and side by side is one of the main principles of Azerbaijan society. Even despite the fact that twenty years passed after the beginning of the war in NagornoKarabakh, Azerbaijani society continues to maintain harmony between religious and ethnic groups [3-6].

\section{Applied significance of research of economic and natural resources}

After the publiction of the 1987 Brundland Report, a number of international and national organizations was developed compleks of the one and other aspects of the sustaianble strategy.

These achivements was received an impetus from international levels after recieved of the plan about "The agenda of the XXI century" in the World Summit.

The 40th chapter of this plan should emphasized that, the countries and international governmental and non-governmental organizations should be work indicators of the sustainable strategy and conseptions should be coordinate in regional and international levels.

The world countries of the United Nations Organizations are divided into four social, economical, ecological and organizational aspects in accordance with concept of the methodology of the sustainable development.

In the fist time learning of the international scientific literature in the collective work, with energy methodology of the indicators of sustainable development which is joint prepeared by United Nations Organization, the International Nuclear Energy Agency, the International Energy Agency, Eurostar and Environmental protection organizatins of the European Union and prepared by University of Calgary of the Canada analyses of the "Power metodology of the sustainable development" are present.

Actual problems of modern times are research of methodology of assessment of competiveness in the context of the concept of the sustainable development in the current stage of Azerbaijan economy. The process in the world Economic systems impacted to the competitiveness of the Azerbaijan economy, formation of the conception of the sustainable development of the country itself is significant. Taking into account this issue, research methodologies of the methodology of the assessment of the competitiveness indicators use for Azerbaijan economy are main aim. To achieve this goal, the set of issues: to prepare system of indicators of the competitiveness methodologies that can be applied to areas of the Azerbaijan economy; to analyze and evaluate the concept of sustainable development in terms of contemporary economic status of the country; to research objective laws between competitiveness indicators with indicators of the concept of sustainable development.

To provide of the sustainable development strategy the same metodology approciate nonconventional energy indicators with macroeconomics and economic increase relotions is main conditions. Scentific importance of the project that, obtain results from the international practice applied in the scientific base of the Azerbaijan Republic and development of the relevant provisions of the state's energy diplomacy will be added.

In Brundland Report of the United Nations ("our common future"), worked to prepare one and other aspects of the indicators complexs of the strategy of sustainable development after publication of a number of international and national organizations.

In 20-22 June 2012 in Pio de Janeiro in Brazil held on "Rio +20 Sustainable Development Conference" of the United Nations.

"Our want the future" of the with the slogan in the final document have been dedicated to usage efficient from non-traditional energy sources as one 
of the main themes of the strategy of sustainable development countries.

On the recomendation of the UNO must cooordinate with country, international country and non-govermental organizations in the international, regional and national levels of the sustainable development strategy indicators.

According to metodology of the sustainable development strategy prepared for world country of the United Nations divide to four social, economical, ecological and organizational aspects.

Measurements of the indicators of the consept of the sustainable development was divided into suitable sub term and parameters of the subjects.

They are divided 14 term in accordance with classifications and in accordance with this term 30 paramters.

Some indicators are belong more than one term and the parametrs of the terms in accordance with classification of the measurements.

Terms and paremetrs of the terms was prepared acoording to conseptual structure of the United Nation Organization in accordance with measurements of the energy indicators of the sustainble development.

The main essence of the strategy of sustainable development of energy performance indicators in the list of the 30 indicators that make up the measurement aspect classification is divided into 3 groups (social, economic and environmental).

30 indicators are divided 3 aspects in the list of the indicators which are organized the main essence of the concept of sustainable development of energy indicators.(social, economic and ecological).

They are divided 7 terms in accordance with classification and 19 parametrs according to terms.

Some indicators are belong more than one term and the parametrs of the terms in accordance with classification of the measurements. The some of the indicators according to the measurement classificationis related more than one themes and the parametrs of themes.

This unique information collection are divided 3 groups as main indicators, 30 indicators.

By the way, scientific works of the collectivity of the Russian Sustainble Develeopment university should be noted. Russian scientist is carred out investigations in the area of the provide separately sustainable developemnt strategy of the Russian in the provinces and big cities.

Purpose of the project, models of the competitiveness strategy has worked to prepare as a tool in the context of the concept of sustainable development of the Azerbaijan Republic. For the first time in the collective learning of the international scientific literature, with the legitimacy of the state's strategy of sustainable development competitiveness facility, the World Economic Forum and the Swiss International Management and Development
Institution methodologies, as well as the concept of sustainable development of the United Nations in connection with the comparative analysis of methods and methodologies are presented.

It should be noted that, Maykl Porterin`s "International Compatitiviness" work according to the term. The author was worked to prepare as larged consept compatitiviness of the state and transnational in the internatioal arena in his work $[1 ; 7]$.

\section{Theoretical importance of comparative research of socio-historical heritage \\ The Republic of Azerbaijan is one the main} country in South Caucasus. According to official data 2.7 million people went to abroad from South Caucasus. The main part of immigrants - about $80 \%$ - has illegal status in foreign country and most of them are youth. Through the profession works $5.1 \%$ but $67.5 \%$ work physical. In most cases, the reason for leaving is material problems. The second main problemof immigrants is feeling of discrimination (might be just subjective), which push for insulation in order to avoid conflicts.

How is experienced discrimination and discrimination empirically developing in Europe? How can the effort to learn empirically institutional barriers that excludeopenness between cultures? To answer the questions, first of all should explain the immigrants structural unit - Diaspora:

Diaspora not forms just as a result of ethnic and religious persecution. Diasporacan be defined, as the collective identity of the group, who voluntarily left their homeland and alsosharedthe "foreign" myth of the common origin and history as strong, identityfiltering connection with the past, to a lost homeland (at least to that what is called homeland by this group). Religion may be crucial for this group, however not very necessary. In the case of South Caucasian Diaspora religious rituals and affiliation is an important point, which can be a hindering for integration in a foreign environment.In addition, it is important to consider marriages between members of the Diaspora, and few number of mixed marriages. However, in accordance with the last year data, the percentage of mixed marriages within the community has increased, that increase connections within the cultures and removes the isolation requirement, due to avoid conflict. Mixed families ensure not just integration of residentpeople but as well the communication of Diaspora.

There are so-called "Victim Diaspora", such as the Jewish, cultural Diaspora, for example the Caribbean African slaves from the United States and Great Britain were created as Diasporas. In addition, the late medieval and early modern period trading communities of the Mediterranean Sea space.

There are different opinions regarding the type of South Caucasian Diaspora. In accordance with consideration of several factors may advise that 


\begin{tabular}{|c|c|c|c|c|c|c|}
\hline Impact Factor: & $\begin{array}{l}\text { ISRA (India) } \\
\text { ISI (Dubai, UAE } \\
\text { GIF (Australia) } \\
\text { JIF }\end{array}$ & $\begin{array}{l}=1.344 \\
=0.829 \\
=0.564 \\
=1.500\end{array}$ & $\begin{array}{l}\text { SIS (USA) } \\
\text { PИНЩ (Russia } \\
\text { ESJI (KZ) } \\
\text { SJIF (Morocco }\end{array}$ & $\begin{array}{l}=0.912 \\
=0.207 \\
=4.102 \\
=\mathbf{2 . 0 3 1}\end{array}$ & $\begin{array}{l}\text { ICV (Poland) } \\
\text { PIF (India) } \\
\text { IBI (India) }\end{array}$ & $\begin{array}{l}=6.630 \\
=1.940 \\
=4.260\end{array}$ \\
\hline
\end{tabular}

South Caucasian Diaspora belong to the "Victim Diaspora":

The important factor in the survey is the attitude of different Diaspora to each other and determination of identity. Determination of identity, as God's chosen people, generally is characteristic phenomenon for Diaspora conservation. Currently there isappeareda new non-religion motivated Diaspora in Germany, that helps to improve integration.

Germany has introduced many innovations in confessional migration during the last years, such as the workshops and trainingproduced by European Institute of History. Also very important is a comparative study of the Diaspora, when provide study of political, or cultural Diaspora beside "victim Diaspora". Which includes the Diaspora experience mechanisms of integration and assimilation in accordance with the historical model. Provides so-calledreligious migration motives and the multicultural impacts analys, which is unique innovationnot just in European space.

\section{The overall picture of migration in 2014-2016}

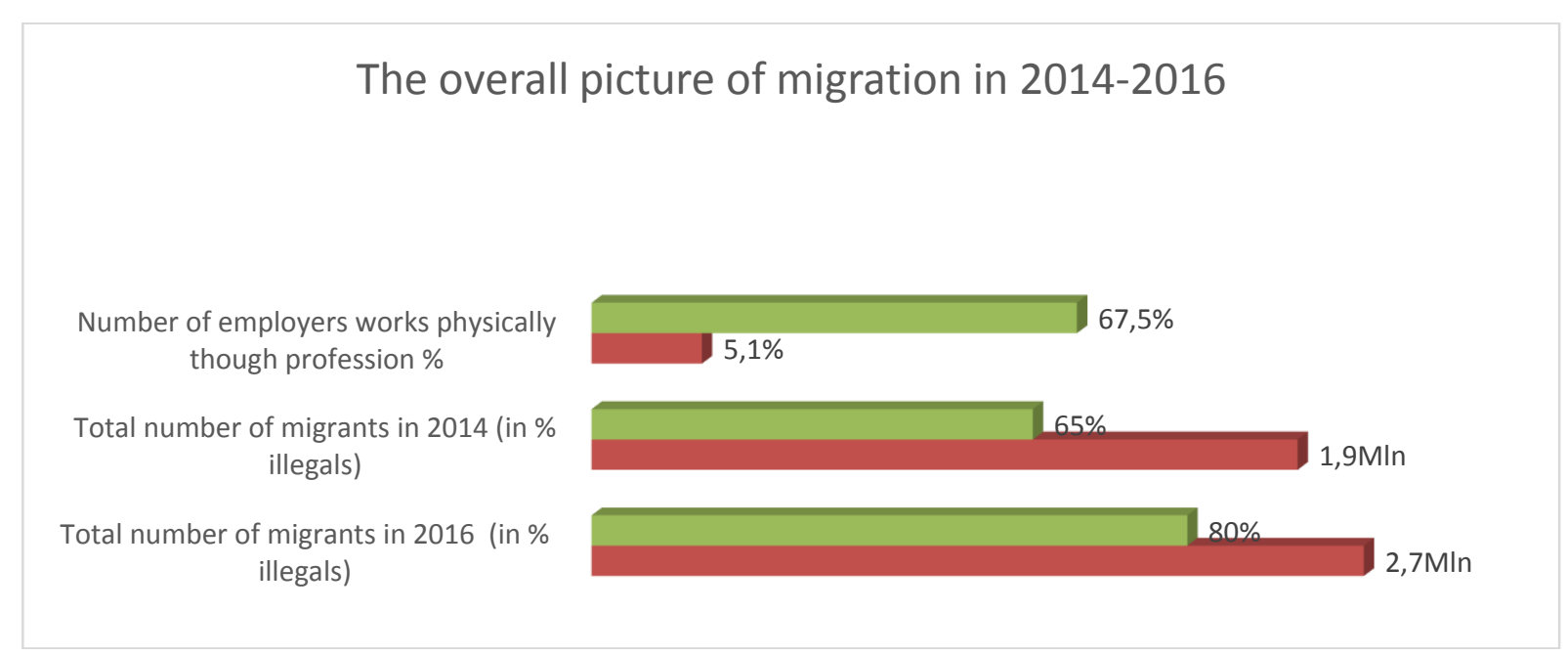

Picture 1 - The overall picture of migration in 2014-2016.

\section{Conclusion}

Historical aspects: Ethnolinguistic identity of the Azerbaijan based on materials of Safavid Empire is one of the most disputable issues in historiography. Partly under the influence of paniranism, ethnopolitical bias, partly due to weak analyses of historical sources (especially "Safvat as-safa" by Ibn Bazzaz that is the first hagiography of the Safavids), partly due to presentation of Azerbaijan as a part of "Iran" in western historiography most western researchers mistakenly present the Azerbaijani Safavids as an "Iranian dynasty". For example, according to E.Yarshater, the origins of the Safavids are clouded in obscurity. Nevertheless, he claims the Safavids to be originally an Iranian-speaking clan (perhaps of Kurdish origin), that was Turkified and adopted Turkish as their vernacular. J.R.Perry adheres the same concept. According to R.Savory, the Safavid family was of indigenous Iranian stock, and not of Turkish ancestry as is sometimes claimed. R.Savory says that "the creation of the Safavid state in 1501 marks a watershed in Iranian history in a number of ways. First, the whole of the area historically considered to be the heartlands of Iran was reunited under the rule of one Persian king (albeit he spoke the Azeri dialect of Turkish) for the first time since the Arab Conquest of Iran more than eight and a half centuries earlier. The restoration of Iranian sovereignty by the Safavids, within the traditional boundaries of Iran, naturally heightened Iranian national consciousness or Iranismus..." R.Savory supposes that the family originated in Persian Kurdistan, and later moved to Azerbaijan, where they adopted the Azari form of Turkish spoken there, and eventually settled in the small town of Ardabil some time during the XI century. In Encyclopaedia Britannica, the oldest English-language encyclopaedia, the Safavid dynasty is presented as an Iranian dynasty whose establishment of Shiite Islam as the State religion of Iran was a major factor in the emergence of a unified national consciousness among the various ethnic and linguistic elements of the country. Even if R.Matthee admits that the Safavids set up the state with the assistance of Turkmen tribal forces of eastern Anatolia, he characterizes them as Persians of Kurdish origin. Even on the official site of BBC the eponymous ancestor of the Safavids Shaikh Safi-al-din described as a "Persian nationalist".

So as you can see, unfortunately, western researchers ignore or don't pay attention (maybe even purposely falsificate the real history!) to the irrefutable facts given in medieval sources on the Safavids' being a Turkic and Turcophone family originally from Ardabil in Azerbaijan. There are a lot of facts that the 
Safavids were of a Turkic ethnolinguistic origin Some of them are the diplomatic letters written in Turkic and sent from Safavid shahs to some European emperors as well as from some European emperors to the shahs (for example, the Russian Tsar Michael I's letter to shah Abbas I was written in Turkic), "Divan" of shah Ismail Khatai and quatrains of Shaikh Safi-al-din, the Safavids' eponymous ancestor, both written in Turkic. H.Javadi and K.Burrill stress that the reigns of Ismail I and his son Tahmasb I are considered the most brilliant period in the history of the Azeri Turkish language and literature at this stage of its development. Moreover, the Turkic language was not only the mother tongue of the ruling dynasty, the language of the court, the military and diplomacy but a high-status vernacular and a widespread contact language in the whole Safavid Empire. Moreover, there are a lot of facts about the Turkic origin of the Safavids in "Safvat as-safa" itself, the hagiography of the Safavid dynasty. For example, during the dialog of Shaikh Safi-al-din with murids in such a Persian city as Shiraz he was referred as "pir-i turk" (Turkic Saint) and the village of Ardabil where he was living was called "deh-i turk" (Turkic village). In most medieval sources the Safavid State is called "Devlet-i Kizilbash" since the kizilbash turcomans constituted the main core of the state and its army. Besides, according to "Tarikh-i alam-ara-yi Abbasi" by Iskandar Beg Munshi, 56 of 72 emirs known by names of 114 ones were kizilbash and 61 of them were Turks.

European travelers that visited the Safavid Empire in different periods of time such as A.Olearius, J.Chardin, P.Della Valle, J-B.Tavernier, E.Kaempfer and others witnessed that the Safavids were a Turkic and Turcophone family, the language of court even in the XVI - XVII centuries was Turkic, even the only language that ghulams (non-Turkic military elements) knew was Turkic. According to Pietro Della Valle and Adam Olearius, even during welcome ceremony of foreign guests at the court shah Abbas I used such Turkic words as "«Xoş gəldin», «Səfa gəldin»". As Adam Olearius notes, during the feast devoted to the foreign guests shah Abbas I spoke Turkic: "Suffre Hakine Schahe doevvletine, Kasiler kuwetine. Alla dielum". Besides, he also states that most of the Persians learnt the Turkic and the Persian was heart seldom at the court, even the children were taught the Turkic.

Nevertheless, along with some facts of distortion there are a number of western researchers (for example, such outstanding scholars as R.Frye, M.Mazzaoui, M.Price, T.Sonn, D.Ayalon, A.Goldschmidt, L.Davidson and others) who acknowledge the Safavids as a Turkic dynasty. A famous German philologist and turkologist best known for his studies of the Turkic languages G.Doerfer talking about the long-lasting Iranian-Azeri symbiosis pointed that many Azeri words (about 1200 words!) entered Persian, since Iran was governed mostly by Azeri-speaking rulers and soldiers since the $16^{\text {th }}$ century. Moreover, he stresses that the Azeri language belongs to the Oghuz branch of the Turkic language family. According to H.Stein, "a specific Turkic language was attested in Safavid Persia during the XVI and XVII centuries, a language that Europeans often called Persian Turkish ("Turk Agemi", "lingua turka agemica"), which was a favourite at the court and in the army because of the Turkish origin of the Safavid dynasty. The original name was just türki. That language might generally be identified as Middle Azerbaijanian".

The Safavid shahs themselves claimed to be Sayyids - descendants of the Islamic prophet Muhammad, although many scholars have cast doubt on this claim. In the oldest manuscript of "Safvat assafa" written by Ibn Bazzaz in 1350 the origin of the Safavids is traced to Piruz Shah Zarrin Kulah, while in the later versions of the manuscripts Shaikh Safi's ancestry is traced back to the seventh imam of the Twelver Shiah, Musa al-Kazim. The Safavids after the establishment of the Safavid state fabricated evidence to prove that the Safavids were Sayyids. The main aim of the Safavids in revision of the "Safvat as-safa" and, as a result, falsification of their genealogy was to justify their political legitimacy and fight the claims of the competing Islamic empires, in particular the Ottoman Empire. According to T.Swietochowski, shah Ismail I made the Shia branch of Islam the official religion of the empire, thus setting the Azeris firmly apart from the ethnically and linguistically similar Ottoman Turks, who were Sunni Muslims. As we know the Ottoman Empire was the bitter enemy of the Safavids [59, 23]. But R.Savory mistakenly claims that textual changes were designed to obscure the Kurdish origins of the Safavid family [61, 339].

Thus, one of the main reasons of distortion of ethnolinguistic identity of the Safavid state in Anglophone historiography is ignoring Azerbaijan by western scholars as a sovereign political entity, presenting it as a part of Iran and, as a result, ignoring the presence of strong Turkic component in ethnopolitical history of Azerbaijan until the Seljuk migration in the XI century when most of them settled here. Moreover, after the misconception of an ancestor of the Safavids Piruz Shah al-Kurdi Zarrin Kulah as a Kurd by an outgoing Iranian historian Ahmad Kasravi in 1930s most western researchers started to "iranize" the Safavids and present them as an Iranian or Kurdish dynasty that was turkified only after the settlement in Ardabil in the XI century.

Modern aspects: Connected with the fact that the contribution of experts from the World Economic Forum, assessment of the macro-and microeconomic competitiveness was analyzed (according with 20122013 years) and compared with the methodology of the 144 countries. The main indicators of the 


\begin{tabular}{|c|c|c|c|c|c|c|}
\hline Impact Factor: & $\begin{array}{l}\text { ISRA (India) } \\
\text { ISI (Dubai, UAF } \\
\text { GIF (Australia) } \\
\text { JIF }\end{array}$ & $\begin{array}{l}=1.344 \\
=0.829 \\
=0.564 \\
=1.500\end{array}$ & $\begin{array}{l}\text { SIS (USA) } \\
\text { PИНЦ (Russia) } \\
\text { ESJI (KZ) } \\
\text { SJIF (Morocco) }\end{array}$ & $\begin{array}{l}=0.912 \\
=0.207 \\
=4.102 \\
=\mathbf{2 . 0 3 1}\end{array}$ & $\begin{array}{l}\text { ICV (Poland) } \\
\text { PIF (India) } \\
\text { IBI (India) }\end{array}$ & $\begin{array}{l}=6.630 \\
=1.940 \\
=4.260\end{array}$ \\
\hline
\end{tabular}

methodology are divided into 12 groups and 103 criterions.

This unique data collection are divided into 4 gorups and 20 indicators and 314 criterions.

It is necessary is noted that, collective's works of the International Relations of the Russian Scientific Academy and World Economics Institute in connected with combativeness problems.

Russian authors are researched with assessments of the combativeness in the level macro and micro economics and in the field of application in Russian economics.

Of cardinal importance in the changing economic infrastructure, primarily affecting the three main directions of international economic the need to:

The first anti-monopoly law by the state in order to create conditions for equal competition significantly enhances performance;
The second, more intense competition in the market for the creation of the internal market by the subjects of the new necessary to conduct the foreign, as well as improved access to markets is essential;

Third, the current conditions of the industry's most advanced telecommunications facilities at all levels (cellular, cable, satellite, and video connections facsimile, Internet, etc.). Competition is not possible to be applied, so that the goods and services markets, the situation is changing every day, enough about access to information is very important. Azerbaijan's economy is one of the weakest parts of it yet.

An active policy of taking into account the above mentioned, the development of the national economy is necessary, the actual solution of the problem (the country's economic growth rates and living standards of the population) can bring [11, 483].

\section{References:}

1. Akimova TA, Moseykin YuN (2009) Ekonomika ustoychivogo razvitiya. M.: Ekonomika, $430 \mathrm{p}$.

2. Guliyeva NM, Häsänov EL (2014) Die traditionelle Gändschänischen Teppiche von Zeitraum der Aserbaidschanischen Gelehrten und Dichter Mirsä Schäfi Waseh als ethnoanthropologische quelle (XIX Jahrhundert). European Applied Sciences, 2, p. 3-5.

3. Hasanov EL (2016) Innovative basis of research of technologic features of some craftsmanship traditions of Ganja (On the sample of carpets of XIX century). International Journal of Environmental and Science Education, 11(14), p. 6704-6714.

4. Energy Indicators for sustainable development: Guidelines and methodologies (2005) Vienna: International Atomic Energy Agency, p. 160.

5. Hasanov EL (2015) Multidisciplinary approach to investigation of the basic handicraft branches of Ganja till the XX century. ISJ Theoretical \& Applied Science 1(21): p. 7-15. DOI: http://dx.doi.org/10.15863/TAS.2015.01.21.2

6. Hasanov EL (2012) Innovational ethnographic facts on investigation and teaching of some basic decorative - applied arts of Ganja of the XIX - XX centuries. Applied and Fundamental Studies: Proceedings of the 1st International Academic Conference. Saint Louis: Publishing
House - Science and Innovation Center, Saint Louis, p. 400-403.

7. Porter M (1993) Mezhdunarodnaya konkurentsiya. Per. s angl. Pod red. i s predisloviem V.D. Shchetinina. M.: Mezhdunarodnye otnosheniya, $896 \mathrm{p}$.

8. Hasanov E.L. (2017) About research of features of legal culture on the basis of historical-literary heritage. Information (Japan), 20(4), p. 22892296.

9. Konkurentosposobnost' Rossii v global'noy ekonomiki (2003) M.: Mezhdunarodnye otnosheniya, $376 \mathrm{p}$.

10. Hasanov EL (2015) To the Question on Research of Craftsmanship Traditions of Ganja of XIX - First Half of XX Centuries. Mediterranean Journal of Social Sciences, vol. 6, № 1, Part S1, p. 433-437. Doi:10.5901/mjss.2015.v6n1s1p433

11. Indicators of Sustainable Development: Framework and methodologies (1996) United Nations, p. 483.

12. Häsänov EL (2012) Die Gändschänischen teppiche von XIX - XX Jahrhundert als geschichtliche - ethnographische quelle. European Science and Technology (Die Europäische Wissenschaft und die Technologien): 2nd International scientifi $\mathrm{c}$ conference. Bildungszentrum Rdk e. V. Wiesbaden, p. 26-27. 
13. Hasanov SL (2014) About innovative basis of research of constructive parameters of plant for dose of tanner materials in a food industry. ISJ Theoretical \& Applied Science 8(16): p. 1-3. DOI: http://dx.doi.org/10.15863/TAS.2014.08.16.1

14. The Global Competitiveness Report (2012) Geneva: World Economy Forum, 2010. 527 p.

15. Gasanov SL (2015) Innovative approach to the research of some constructive parameters of plant for dose of tanner materials in a food industry. Molodoy uchenyy, 2015, №7, p. 110112.

16. Mirkin BM, Naumova LG (2006) Ustoychivoe razvitie. M.: Universitetskaya kniga, 312 p.

17. Teleuyev GB, Akulich OV, Kadyrov MA, Ponomarev AA, Hasanov EL (2017) Problems of Legal Regulation for Use and Development of Renewable Energy Sources in the Republic of Kazakhstan. International Journal of Energy Economics and Policy, vol.7, № 5, p. 296-301.

18. Ustoychivoe ekonomicheskoe razvitiya $\mathrm{V}$ usloviyakh globalizatsii i ekonomiki znaniy: kontseptual'nye osnovy teorii i praktiki upravleniya (2007) Pod red. V.V. Popkova. M.: Ekonomika, 295 p.

19. Guliyeva NM, Hasanov EL (2013) Investigation of basic decorative-applied arts of Ganja on the basis of some innovative arguments and technologies. Science and Society: Proceedings of the 3rd International scientific-practical conference. London: SCIEURO, p. 281-291.

20. Həsənov EL (2012) Gəncə İmamzadə türbəsi (tarixi-etnoqrafik tədqiqat). 1-ci nəşr. Bakı: Elm və təhsil, $268 \mathrm{p}$.

21. Ofəndiyev RS (1976) Azərbaycanın dekorativtətbiqi sənətləri. Bakı: İşıq.

22. Ohmədov FM (2007) Gəncənin tarix yaddaş1. Gəncə: Elm.

23. Gəncənin məhəllə adları (1978) Elm və həyat jurnal1, №10.

24. Həmidova İ (2000) Azərbaycan parça sənətinin tarixi inkişaf yolları. Elmi axtarışlar, VIII toplu, Bak1.

25. Həsənov EL (2015) Gəncə İmamzadə türbəsi ənənəvi multikulturalizm abidəsi kimi. Qafqazda mədəni-dini irsin qorunması mövzusunda beynəlxalq konfransın materialları. Bak1, 2015, p. 117-120.

26. Azərbaycan etnoqrafiyası (2007): 3 cilddə, I cild, Bak1: Şərq-Qərb, 544 p.

27. Hasanov EL (2017) About research of features of legal culture on the basis of historical-literary heritage. Information (Japan), 20(4), p. 22892296.

28. Azərbaycan arxeologiyası (2008): 6 cilddə, VI cild. Bakı: Şərq-Qərb nəşriyyatı, 632 p.
29. Guliyeva NM, Häsänov EL (2014) Die traditionelle Gändschänischen Teppiche von Zeitraum der Aserbaidschanischen Gelehrten und Dichter Mirsä Schäfi Waseh als ethnoanthropologische quelle (XIX Jahrhundert). European Applied Sciences, 2, p. 3-5.

30. The dawn of Art. (1974) Leningrad: Aurora Art Publishers, $196 \mathrm{p}$.

31. Hasanov EL (2016) About comparative research of poems "Treasury of Mysteries" and "Iskandername" on the basis of manuscript sources as the multiculturalism samples. International Journal of Environmental and Science Education, 11(16), p. 9136-9143.

32. Hasanov EL (2016) Innovative basis of research of technologic features of some craftsmanship traditions of Ganja (On the sample of carpets of XIX century). International Journal of Environmental and Science Education, 11(14), p. 6704-6714.

33. Teleuyev GB, Akulich OV, Kadyrov MA, Ponomarev AA, Hasanov EL (2017) Problems of Legal Regulation for Use and Development of Renewable Energy Sources in the Republic of Kazakhstan. International Journal of Energy Economics and Policy, vol.7, № 5, p. 296-301.

34. Bosworth C. Edmund (2000) Ganja (angl.). Iranica (December 15, 2000).

35. Hasanov EL (2015) Multidisciplinary approach to investigation of the basic handicraft branches of Ganja till the XX century. ISJ Theoretical \& Applied Science 1(21): 7-15. DOI: http://dx.doi.org/10.15863/TAS.2015.01.21.2

36. Bünyadova ŞT (1992) Nizami və etnoqrafiya. Bakı: Elm.

37. Hasanov EL (2015) To the Question on Research of Craftsmanship Traditions of Ganja of XIX - First Half of XX Centuries. Mediterranean Journal of Social Sciences, vol. 6, № 1, Part S1, p. 433-437. Doi:10.5901/mjss.2015.v6n1s1p433

38. Həmidova İ (2000) Azərbaycan parça sənətinin tarixi inkişaf yolları. Elmi axtarışlar, VIII toplu, Bakı.

39. Chelkowski P (2008) Nizami Gandjawi, jamal al-Din Abu Muhammad Ilyas b. Yusuf b. Zaki Muayyad. Encyclopaedia of Islam. Edited by: P. Bearman, Th. Bianquis, C.E. Bosworth, E. van Donzel and W.P. Heinrichs. Brill.

40. Həsənov EL (2015) Gəncə İmamzadə türbəsi ənənəvi multikulturalizm abidəsi kimi. Qafqazda mədəni-dini irsin qorunması mövzusunda beynəlxalq konfransin materialları. Bak1, 2015, p. 117-120.

41. Həvilov HA (1991) Azərbaycan etnoqrafiyası. Bak1: Elm.

42. Gasanov EL (2015) Ob innovatsionnykh rezul'tatakh istoriko-etnograficheskogo 


\begin{tabular}{|c|c|c|c|c|c|c|}
\hline Impact Factor: & $\begin{array}{l}\text { ISRA (India) } \\
\text { ISI (Dubai, UAF } \\
\text { GIF (Australia) } \\
\text { JIF }\end{array}$ & $\begin{array}{l}=1.344 \\
=0.829 \\
=0.564 \\
=1.500\end{array}$ & $\begin{array}{l}\text { SIS (USA) } \\
\text { PИНЦ (Russia } \\
\text { ESJI (KZ) } \\
\text { SJIF (Morocco }\end{array}$ & $\begin{array}{l}=\mathbf{0 . 9 1 2} \\
=\mathbf{0 . 2 0 7} \\
=\mathbf{4 . 1 0 2} \\
=\mathbf{2 . 0 3 1}\end{array}$ & $\begin{array}{l}\text { ICV (Poland) } \\
\text { PIF (India) } \\
\text { IBI (India) }\end{array}$ & $\begin{array}{l}=6.630 \\
=1.940 \\
=4.260\end{array}$ \\
\hline
\end{tabular}

issledovaniya khudozhestvennoy keramiki drevney Gyandzhi. Novyy universitet Aktual'nye problemy gumanitarnykh i obshchestvennykh nauk. № 8-9 (53-54). DOI: 10.15350/2222-1484.2015.8-9

43. Məmmədov FN (1976) XIX əsrdə Gəncə şəhərinin ərazisi, əhalisi və idarəsi (1868-ci ilə qədər). Azərbaycan SSR Elmlər Akademiyasının Xəbərləri (Tarix, fəlsəfə və hüquq seriyası), №3, p. 30-37.

44. Mustafayev A (2001) Azərbaycanda sənətkarlıq. Bakı: Altay.

45. Smith WB, Hasanov EL (2013) Importance of handicraft traditions in investigation of history of urban culture in Ganja. ISJ Theoretical \& Applied Science 11(7): 61-66. doi: http://dx.doi.org/10.15863/TAS.2013.11.7.10

46. Tərlanov M, Ofəndiyev R (1960) Azərbaycan xalq sənəti. Bakı: Uşaq gənc nəşr.

47. Cavadov QC (1977) Azərbaycanda ağacişləmə sənəti haqqında. AEM. III buraxılış.

48. Ofəndiyev RS (1966) Azərbaycanın bədii sənətkarlığı. Bakı: Azərnəşr.

49. Geneviève Zarate, Danielle Levy, Claire Kramsch (2011) Handbook of Multilingualism and Multiculturalism. Archives contemporaines. p. 377.

50. Al'tman MM (1949) Istoricheskiy ocherk goroda Gyandzhi. Baku: Akademiya Nauk Azerbaydzhanskoy SSR, p. 41.

51. Hasanov EL (2014) Basic craftsmanship branches of Ganja of the second half of XIXbeginning of XX centuries as a historicethnographical source. Asian Journal of Social Sciences and Humanities, vol. 3, Number 3, Oyama (Japan).

52. Guliyeva NM, Hasanov EL (2012) About ethnographic-archaeological research of some handicraft branches of Ganja during XIX XX centuries. Progressive scientific explorations - 2012: Proceedings of the 8th International scientific-practical conference. Prague: Publishing House - Education and Science s. r.o., p. 73-75.
53. Həsənov EL (2012) Gəncə İmamzadə türbəsi (tarixi-etnoqrafik tədqiqat). 1-ci nəşr. Bakı: Elm və təhsil, $268 \mathrm{p}$.

54. Gəncənin məhəllə adları (1978) Elm və həyat jurnal1, №10.

55. Pachkalov AV (2011) Neopublikovannyy klad zolotykh vizantiyskikh i musul'manskikh monet iz Arkheologicheskogo muzeya Gyandzhi. Sovremennoe sostoyanie i perspektivy razvitiya muzeev. Materialy Mezhdunarodnoy nauchnoy konferentsii. Baku, 2011.

56. Häsänov EL (2012) Die Gändschänischen teppiche von XIX - XX Jahrhundert als geschichtliche - ethnographische quelle // European Science and Technology (Die Europäische Wissenschaft und die Technologien): 2nd International scientifi c conference. Bildungszentrum Rdk e. V. Wiesbaden, p. 26-27.

57. Burton-Brown T (1951) Excavations in Azerbaijan, 1948. London.

58. Hasanov EL (2012) Innovational ethnographic facts on investigation and teaching of some basic decorative - applied arts of Ganja of the XIX - XX centuries. Applied and Fundamental Studies: Proceedings of the 1st International Academic Conference. Saint Louis: Publishing HouseScience and Innovation Center, Saint Louis, p. 400-403.

59. Stern, S.M. (1960) The Early Ismaili Missionaries in North - West Persia and in Khurasan and Transoxania. Bulletin of the school of Oriental and African Studien. University of London, 23, 1.

60. Guliyeva NM, Hasanov EL (2013) Investigation of basic decorative-applied arts of Ganja on the basis of some innovative arguments and technologies. Science and Society: Proceedings of the 3rd International scientific-practical conference. Volume 1, London. p. 281-291.

61. (1853) Caucasian calendar for 1854. Tbilisi. p. 338-341.

62. Nemət MS (1992) Azərbaycanda pirlər. Bakı: Azərnəşr, $104 \mathrm{p}$. 